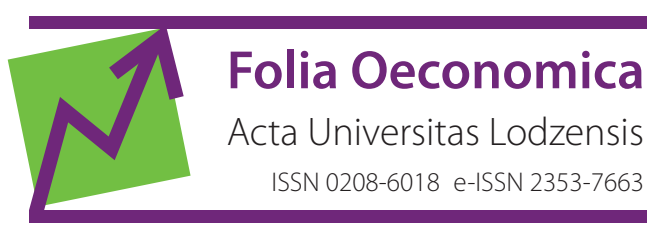

www.czasopisma.uni.lodz.pl/foe/

$1(327) 2017$

DOI: http://dx.doi.org/10.18778/0208-6018.327.07

\author{
Maria Klonowska-Matynia \\ Politechnika Koszalińska, Wydział Nauk Ekonomicznych, \\ Katedra Ekonomii, maria.klonowska-matynia@tu.koszalin.pl
}

\title{
Czynniki edukacyjne a przestrzenne rozmieszczenie kapitału ludzkiego na obszarach wiejskich w Polsce
}

Streszczenie: Celem artykułu jest określenie i ocena przestrzennego rozmieszczenia kapitału ludzkiego na obszarach wiejskich w Polsce i dokonanie klasyfikacji badanych gmin pod względem zasobów kapitału ludzkiego. Podjęto również próbę zbadania kierunków i zidentyfikowania głównego czynnika odpowiedzialnego za to zróżnicowanie. Analizę oparto na wybranych cechach opisujących jakość systemu edukacji. W badaniu wykorzystano wybrane metody hierarchizacji i klasyfikacji obiektów wielocechowych. W celu określenia osiągniętego poziomu zasobów KL obszarów wiejskich zastosowano porządkowanie liniowe w oparciu o metodę sum standaryzowanych wartości. W efekcie przyporządkowano każdemu z krajów względny wskaźnik zasobów KL. Badania potwierdzają, że: poziom kapitału ludzkiego na obszarach wiejskich jest ogólnie niski, zdywersyfikowanie przestrzeni wiejskiej jest silne, polaryzacja ma charakter dualny w układzie centrum - peryferia, wysoka jakość sfery edukacyjnej i jej dostępność dominuje nadal w ośrodkach wzrostu, a promień dyfuzji nie wykracza w zasadzie poza pierścień strefy podmiejskiej. Głównym źródłem danych były: GUS BDL, OKE, NSP.

Słowa kluczowe: obszary wiejskie, kapitał ludzki, edukacja, zróżnicowanie obszarów wiejskich JEL: C40, C31, O15, 125 


\section{Wprowadzenie}

Przestrzeń wiejska w Polsce jest silnie zróżnicowana. Badania nad rozwojem jej obszarów od lat podejmują niełatwą próbę ustalenia przyczyny tego zróżnicowania i zidentyfikowania kluczowych czynników sukcesu (rozwoju) danej jednostki. Dorobek teorii rozwoju obszarów wiejskich chociaż bogaty, nie pozwala sporządzić uniwersalnej klasyfikacji czynników rozwoju obszarów wiejskich. Bieżące badania układów przestrzennych potwierdzają, że rozwój obszarów wiejskich w Polsce rysuje się na linii rdzeń - peryferie i jest wypadkową wielu działających jednocześnie czynników (Stanny, 2013: 284). Przez lata nadrzędną rolę w tym procesie przypisywano uwarunkowaniom historycznym (Stanny, 2013: 12; Stanny, Czarnecki, 2011: 57-60), podczas gdy przedstawiciele nowego podejścia w teorii rozwoju obszarów wiejskich podkreślają, że współcześnie szanse rozwojowe determinowane są w głównej mierze przez czynniki jakościowe, tj.: kapitał ludzki i społeczny, kapitał kreatywny, wiedzę, instytucje i organizacje otoczenia rynkowego czy też istniejącą strukturę funkcjonalną gmin (Czapiewski, 2011: 201-202, Domański, 2007: 85). Przedmiotem odrębnej dyskusji pozostaje kwestia wyraźnego podziału pomiędzy uwarunkowaniami danego miejsca a czynnikami rozwoju (Stanny, 2013: 217). Nierozstrzygniętą kwestią nadal pozostaje, czy jest on efektem czy zasobem rozwoju lokalnego. Niniejszy artykuł podejmuje próbę uzupełnienia luki empirycznej na temat przestrzennego zróżnicowania obszarów wiejskich w Polsce w kontekście czynników edukacyjnych warunkujących poziom kapitału ludzkiego. Jako cel główny wyznaczono określenie i ocenę przestrzennego rozmieszczenia kapitału ludzkiego na obszarach wiejskich w Polsce i dokonanie klasyfikacji badanych gmin pod względem zasobów kapitału ludzkiego. Podjęto również próbę zbadania kierunków tego zróżnicowania i zidentyfikowania głównego czynnika odpowiedzialnego za to zróżnicowanie.

\section{Kapitał ludzki i czynnik edukacyjny}

Teoria kapitału ludzkiego nie wypracowała jednoznacznej interpretacji pojęcia $\mathrm{ka}$ pitał ludzki, a co się z tym wiąże - sposobu wyceny jego wartości. Próba definiowania kapitału ludzkiego najczęściej podejmowana jest na drodze opisowo-wyjaśniającej. Większość badaczy przyjmuje, podobnie jak Adam Smith i inni klasycy, że istotę potencjału człowieka stanowi jego wiedza i umiejętności (Beach, 2009: 24-38), mające kluczowe znaczenie dla jego aktywności na rynku pracy. Rola jakościowych czynników, tj. edukacji i wykształcenia, uwzględniana jest w powszechnie przyjętych kryteriach wyrażania istoty kapitału ludzkiego. Już w latach 60. XX w. Theodore Schultz dowodził tezy, że szybszego wzrostu dochodu narodowego należy upatrywać we wzroście poziomu wykształcenia pracujących 
(Schultz, 1963: 6-8). Zależności pomiędzy latami edukacji a wynagrodzeniami analizował także Jacob Mincer, który w 1962 r. w swoim modelu udowadniał, że uzyskiwane dochody są determinowane przez liczbę lat spędzonych w szkole (Mincer, 1962, 58-60). Wkład poziomu edukacji we wzrost ekonomiczny był przedmiotem dalszych badań Schultza (Schultz, 1980, 438) oraz Richarda Nelsona i Edmunda Phelpsa (Nelson, Phelps, 1966: 69-75). Byli oni zdania, że „wykształcenie jest przypuszczalnie szczególnie istotne przy spełnianiu funkcji wymagających przystosowania do zmian”. Zdaniem autorów relatywnie wysoka jakość kapitału ludzkiego pozwala lepiej funkcjonować w zmieniającym się środowisku technologicznym. Edukacja i umiejętności determinują stopień, w jakim wiedza i technologia może być przenoszona i absorbowana do kreowania nowych rodzimych pomysłów (Amsden, 1992) oraz konkurowania na globalnych rynkach (Carnoy, Castells, 2001: 1-18; Green, 1997).

Znaczenie jakości kształcenia, także na niższym poziomie, bardzo dobrze ilustruje wynik analizy przeprowadzonej przez Erica Hanusheka i Ludgera Woessmanna, którzy potwierdzili związek liniowy statystycznie istotny pomiędzy przeciętnym tempem wzrostu realnego PKB per capita, a przeciętną liczbą lat kształcenia (Hanushek, Woessmann, 2011: 89-200; Hanushek, Woessmann, 2008: 607-668). Badania innych autorów potwierdzają, że źródłem wzrostu wydajności pracy w średnim okresie w krajach o niskim poziomie rozwoju mogą być wysokie inwestycje, zarówno w kapitał rzeczowy, jak i kapitał ludzki. Są one niezbędne dla osiągnięcia rozwoju przemysłowego, a poprawa poziomu wykształcenia w tych krajach jest potrzebna, aby zapewnić wzrost zatrudnienia (Hughes, 1991: 213-23; Oketch, 2003: 88-106; Oketch, 2004: 119-136; Oketch, 2006: 554-564). Szereg innych badań empirycznych dokumentuje pozytywny, choć względnie zróżnicowany wpływ poziomu edukacji na wysokość zarobków w różnych okresach i w różnych krajach $^{1}$ (Fuente, Ciccone, 2003: 11).

Gary Becker, światowy autorytet w tej dziedzinie, twierdził, że kapitał ludzki ma charakter dynamiczny i askryptywny. Oznacza to, że może być on pomnażany, oraz że nie sposób nikogo od niego oddzielić, tak jak jest to możliwe w przypadku innych kapitałów (Becker, 1993: 16). Wszelkie formy nakładów na poszerzanie wiedzy autor określił mianem inwestycji. Jego zdaniem inwestycje te „wpływają na przyszły pieniężny i fizyczny dochód przez powiększanie zasobów w ludziach" (Becker, 1975: 9). Prace Beckera dowodzą niekwestionowanej roli wykształcenia wyższego. Po pierwsze dokumentują, iż w porównaniu do osób, które ukończyły szkołę średnią, absolwenci uniwersytetów wykazują wyższy poziom inteligencji i większe dochody, są zdrowsi i mają lepiej rozwinięte kompetencje społeczne. Po drugie, jak wynika z badań, stopa zwrotu z prywatnych inwestycji w eduka-

${ }^{1}$ Największy zysk z edukacji osiągnięto w Irlandii (12\%) a najmniejszy w krajach skandynawskich (około 4\%). Przeciętna dla Europy wyniosła 6,5\%. 
cję na poziomie wyższym przewyższała stopę zwrotu z innych kapitałów (Becker, 1975: 247). Ciekawe wyniki badań dotyczące inwestycji w kapitał ludzki zaprezentował także James Heckman. Udowodnił tezę, że najlepszym okresem dla podejmowania inwestowania na rzecz rozwoju zdolności i umiejętności jest wczesne dzieciństwo (Cuhna i in., 2005: 3, 84). Jak podkreśla inny autor, B. Weisbrodt, nakłady niematerialne w człowieka są warunkiem wzrostu gospodarczego oraz poprawy zdrowotności, dobrobytu i wytworzenia się wielu korzyści społecznych (Weisbrodt, 1962: 106-123). Efektem inwestycji w sektor edukacji niezaprzeczalnie jest szybki wzrost gospodarczy i podniesienie poziomu życia obserwowane prawie we wszystkich regionach świata od czasów rewolucji przemysłowej. Doświadczenia krajów wschodniej Azji, m.in. Japonii, Korei, Tajwanu and Singapuru, potwierdzają sukces gospodarczy uzyskany poprzez między innymi przedłużone inwestycje w kapitał ludzki w długim okresie (Tilak, 2002; Tilak, 2004: 343-359).

Rolę kapitału ludzkiego doceniono w teoriach wzrostu endogenicznego. Na przykład model Paula Romera zakładał wzrost gospodarczy wprost ze wzrostu zatrudnienia w sektorze $(\mathrm{B}+\mathrm{R})$. Ilość dóbr kapitałowych w gospodarce uzależniał od poziomu wiedzy naukowo-technicznej, dla kreacji której decydujące znaczenie, zdaniem autora, mają inwestycje w kapitał ludzki (Romer, 1992: 99). Robert Lucas modelował funkcję produkcji, nie tylko w oparciu o zasoby kapitału ludzkiego w gospodarce, lecz także z uwzględnieniem nakładów kapitału rzeczowego, nakładów pracy przy produkcji dóbr i usług (czas przeznaczony jest na pracę oraz akumulację kapitału ludzkiego) (Lucas, 1988: 4-5). Z kolei Łukasz Jabłoński próbuje dowieść, że na tempo akumulacji kapitału ludzkiego wpływa poziom rozwoju gospodarki na danym etapie, a akumulacja kapitału ludzkiego wynika zarówno z zaszłych decyzji inwestycyjnych, jak i z efektu konwergencji. Oznacza on wzrost zapotrzebowania gospodarki na większą akumulację tego czynnika wytwórczego, co zasadniczo zależy od poziomu rozwoju gospodarki (Jabłoński, 2011: 82).

Kapitał ludzki, podobnie jak kapitał rzeczowy czy finansowy, wykazuje skłonność do koncentracji przestrzennej na obszarach o wysokim poziomie rozwoju społeczno-gospodarczego. Najczęściej zjawisko to występuje w miastach, głównie metropoliach. Wzrost jakości zasobów ludzkich w wymiarze przestrzennym może sprzyjać rozwojowi jednych obszarów lub też marginalizacji innych, doprowadzając do ich peryferyzacji i wyhamowania procesów rozwoju (Gaczek, Komorowski, 2005: 54-55). Zjawisko to nabiera szczególnego znaczenia w przypadku obszarów wiejskich i możliwości (warunków) ich rozwoju. Znamienną cechą większości obszarów wiejskich jest właśnie peryferyjność. $Z$ tego też powodu istotną sprawą, występującą częściej i w większym stopniu niż dla obszarów miejskich, jest możliwość wdrażania optymalnych programów wspierających ich rozwój, opartych na odrębnym instrumentarium, uwzględniającym lokalną specyfikę danej gminy i dostosowanym do występujących lokalnie zasobów i uwarunkowań życia. 
Obszary wiejskie w Polsce kumulują znaczący potencjał ekonomiczny. Przestrzennie dominują nad obszarami zurbanizowanymi, gdyż zajmują ponad 93\% ogólnej powierzchni kraju. O ich sile stanowi również liczba ludności. Wg danych GUS, obszary wiejskie zamieszkuje 15,3 mln osób, tj. prawie 40\% ludności kraju (Obszary..., 2014: 126). Jest to jeden z najwyższych wskaźników w Europie. Dla mieszkańców wsi edukacja przez lata odgrywała ważną rolę w osiąganiu awansu społecznego. Korzystne zmiany w systemie edukacji, zwłaszcza upowszechnienie szkolnictwa wyższego po 1990 r. i zmiana postaw ludności wiejskiej wobec posiadania wykształcenia, przyczyniły się do zmniejszenia dysproporcji pomiędzy miastem a wsią. Niekwestionowanie struktura wykształcenia ludności wiejskiej uległa poprawie. Pomimo tego stan kapitału ludzkiego na obszarach wiejskich w Polsce od lat oceniany jest jako niski, co stawia istotną barierę na drodze ich rozwoju (Klonowska-Matynia, Zdrojewski, 2008: 139-144). Z tego też powodu interesujące wydało się autorowi zweryfikowanie empirycznie, jaki jest rozkład przestrzenny kapitału ludzkiego na obszarach wiejskich w Polsce. Dodatkową przesłanką podjęcia tematu kapitału ludzkiego na wsi jest stosunkowo niewielka liczba opracowań zogniskowanych na kompleksowym opisie badanego problemu. Te najczęściej występujące dotyczą wybranego fragmentu przestrzeni (tj. województwa, regionu), rzadziej analizy empiryczne prowadzone są na poziomie gminnym. Dodatkowo niewielka część z nich ma zasięg ogólnokrajowy. Interesujące wydało się uzyskanie odpowiedzi na pytanie: jak silnie zdywersyfikowana jest przestrzeń wiejska w Polsce pod względem zasobów kapitału ludzkiego.

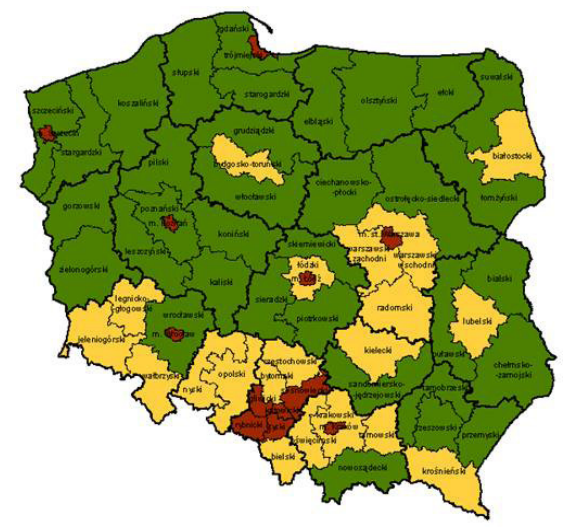

przeważajaco miejskie (PM)

pośrednie (P)

przeważajaco wiejskie (PM)

Rysunek 1. Obszary wiejskie w Polsce wg typologii OECD - zróżnicowanie przestrzenne

Źródło: Główne założenia Strategii zrównoważonego rozwoju wsi, rolnictwa i rybactwa na lata 2012-2020 oraz przebieg prac nad strategią 


\section{Metoda i zakres danych}

Podejście terytorialne w analizach dotyczących zróżnicowania obszarów wiejskich staje się coraz bardziej popularne, głównie ze względu na swój walor aplikacyjny. Opracowania syntetyzujące wiedzę na temat polskiej przestrzeni wiejskiej są pomocne w realizacji efektywnych programów polityki regionalnej (Koncepcja Przestrzennego Zagospodarowania..., 2012), zwłaszcza przy planowaniu optymalnej ścieżki rozwoju danej jednostki czy regionu. Jak podkreśla Stanny, bardziej efektywne okazuje się aktywizowanie rozwoju jednorodnych typów układów lokalnych wg dedykowanego im scenariusza, niż dążenie za wszelką cenę do uzyskania konwergencji (Stanny, 2013: 286). Istotnym krokiem w podejmowanych analizach jest zatem wyodrębnienie względnie jednorodnych typów układów (gmin), aby móc dedykować im wspólny program wspierający ich rozwój dopasowany do ich możliwości i potrzeb.

Klasyfikacja badanego obszaru jest jedną z powszechniej stosowanych metod syntezy szczegółowej informacji na temat przestrzeni wiejskiej. Metoda ta polega na uporządkowaniu zestawu licznych szczegółowych charakterystyk w określoną liczbę bardziej ogólnych klas lub typów, stanowiących pewien wzorzec konfiguracji tych charakterystyk (Mazur, Bański, Czapiewski, Śleszyński, 2015: 7-36). Autor niniejszego artykułu podejmuje próbę pomiaru przestrzennego zróżnicowania obszarów wiejskich w Polsce i dokonuje klasyfikacji badanych gmin pod względem zasobów kapitału ludzkiego, określa kierunki tego zróżnicowania i identyfikuje główny czynnik odpowiedzialny za to zróżnicowanie. Porównania badanych obszarów wiejskich dokonano na podstawie wskaźnika syntetycznego, do oszacowania którego wykorzystano metodę sum standaryzowanych. Zmienna syntetyczna opisuje łączny stopień reprezentowanego zasobu dla poszczególnych gmin. W postępowaniu przygotowawczym dokonano sumowania zestandaryzowanych uprzednio wartości uwzględnionych cech, wśród których cechy będące destymulantami przekształcono, mnożąc ich wartości przez -1. Zmienną syntetyczną opisującą ogólny poziom kapitału ludzkiego przekształcono wg następującej formuty (Nowak, 1990: 80):

$$
W_{i}=\frac{\sum_{j=1}^{k} z_{i j}}{\sum_{j=1}^{k} \max _{i}\left\{z_{i j}\right\}}
$$

gdzie:

$$
z_{i j}=x_{i j}+\left|\min _{i}\left\{x_{i j}\right\}\right| \text { oraz } x_{i j} \text { oznacza wartość cechy } j \text { dla gminy o numerze } i \text {. }
$$


Otrzymany w ten sposób wskaźnik względnego poziomu kapitału ludzkiego przyjmuje wartości z przedziału $<0,1>$, przy czym większa wartość oznacza obiekt lepszy pod względem kryterium ogólnego. Uszeregowanie gmin w oparciu o względny wskaźnik poziomu kapitału ludzkiego pozwala określić te o najwyższym jego poziomie oraz takie, które znajdują się na najgorszej pozycji pod względem analizowanego kryterium. Tymczasem gminy zajmujące w tym szeregu pozycje środkowe odznaczać się mogą dużym zróżnicowaniem pod względem cech uwzględnionych w badaniu, gdyż różne przyczyny mogą spowodować usytuowanie badanych gmin na podobnych pozycjach. W konsekwencji obok siebie (lub w tej samej grupie będącej efektem dokonania klasyfikacji krajów w szeregu strukturalnym o takiej samej rozpiętości klas wskaźnika względnego poziomu rozwoju) mogą się znaleźć obiekty o istotnie odmiennych wartościach analizowanych zmiennych.

Klasyfikację jednostek przestrzennych zrealizowano ex post (por. Stola, 1987; Bański, Stola, 2002; Stanny, 2013). Polegała ona na analizie danych empirycznych, w wyniku której wyróżniono klasy, oddające w optymalny sposób wzajemne podobieństwa i różnice obserwowane w zbiorze analizowanych jednostek przestrzennych. Należy podkreślić, że podobnie jak w przypadku innych badań nad przestrzenią wiejską w Polsce, również i to napotkało szereg ograniczeń. Pierwsze, z którym przyszło zmierzyć się autorowi, to brak uniwersalnej definicji obszaru wiejskiego, pomimo powszechności użycia terminu obszar wiejski (Stanny, 2013: 17-26). Po drugie, specyfika kapitału ludzkiego, jego niematerialny i niejednorodny charakter sprawiły, że jego pomiar okazał się zadaniem niełatwym. Pojawiła się ogromna trudność w przełożeniu języka teorii na język wskaźników empirycznych (np. jak zmierzyć wiedzę, umiejętności, cechy psychiczne itp. (por. Jabłoński, 2012; Kozuń-Cieślak, 2013). Ostatnim utrudnieniem była mocno ograniczona dostępność danych na poziomie gminy, co w istotny sposób zawęziło możliwości doboru mierników. Zgodnie jednak z opinią autorytetów w dziedzinie badań nad rozwojem obszarów wiejskich w Polsce, analiza przestrzenna obszarów wiejskich ma sens na najniższym poziomie agregacji, gdyż pozwala uzyskać obraz zróżnicowania przestrzennego najbliższego rzeczywistości.

Odwołując się do wyżej opisywanych zależności pomiędzy edukacją a jakością kapitału ludzkiego, do budowy wskaźnika wybrano zmienne diagnostyczne związane ze sferą edukacyjną badanych gmin. W postępowaniu badawczym skoncentrowano się wyłącznie na analizie tych cech, które w uproszczony, ale możliwie dokładny i wyczerpujący, a przede wszystkim dostępny sposób oddają charakter danej społeczności, ukazując zróżnicowanie pomiędzy badanymi obiektami. Jednostki terytorialne przyjęte do badania to obszary wiejskie zdefiniowane jako gminy wiejskie i miejsko-wiejskie, wyodrębnione w oparciu o kryterium administracyjne. Ostatecznie analizą empiryczną objęto 2172 gminy, a o zakwalifikowaniu do badania zadecydowała dostępność danych (wykaz cech w tab. 1). 
Tabela 1. Wykaz cech empirycznych przyjętych do badania - składowych wskaźnika poziomu kapitału ludzkiego

\begin{tabular}{|c|c|c|c|}
\hline Cecha & Charakterystyka warunków edukacyjnych & Źródło & $\begin{array}{c}\text { Stymulanta/ } \\
\text { destymulanta }\end{array}$ \\
\hline $\mathrm{X} 1$ & $\begin{array}{l}\text { Udział ludności z wyższym wykształceniem } \\
\text { w ogólnej liczbie ludności dorosłej [w \%] }\end{array}$ & $\begin{array}{c}\text { NSP } \\
2002 / 2011\end{array}$ & $\mathrm{~S}$ \\
\hline $\mathrm{X} 2$ & Współczynnik skolaryzacji brutto SP [w \%] & $\begin{array}{l}\text { GUS BDL } \\
2014\end{array}$ & $\mathrm{~S}$ \\
\hline $\mathrm{X} 3$ & $\begin{array}{l}\text { Współczynnik skolaryzacji brutto gimnazja } \\
\text { [w \%] }\end{array}$ & $\begin{array}{l}\text { GUS BDL } \\
2014\end{array}$ & $\mathrm{~S}$ \\
\hline $\mathrm{X} 4$ & $\begin{array}{l}\text { Udział czytelników bibliotek publicznych } \\
\text { na } 1000 \text { ludności [w \%] }\end{array}$ & $\begin{array}{l}\text { GUS BDL } \\
2014\end{array}$ & $\mathrm{~S}$ \\
\hline $\mathrm{X} 5$ & $\begin{array}{l}\text { Średni wynik sprawdzianu kończącego szkołę } \\
\text { podstawową z języka polskiego [w \%] }\end{array}$ & OKE 2015 & $\mathrm{~S}$ \\
\hline $\mathrm{X} 6$ & $\begin{array}{l}\text { Średni wynik sprawdzianu kończącego szkołę } \\
\text { podstawową z matematyki [w \%] }\end{array}$ & OKE 2015 & $\mathrm{~S}$ \\
\hline $\mathrm{X} 7$ & $\begin{array}{l}\text { Średni wynik sprawdzianu kończącego szkołę } \\
\text { podstawową z języka angielskiego [w \%] }\end{array}$ & OKE 2015 & $\mathrm{~S}$ \\
\hline $\mathrm{X} 8$ & $\begin{array}{l}\text { Średni wynik egzaminu gimnazjalnego - histo- } \\
\text { ria [w \%] }\end{array}$ & OKE 2015 & $\mathrm{~S}$ \\
\hline X9 & $\begin{array}{l}\text { Średni wynik egzaminu gimnazjalnego - język } \\
\text { polski [w \%] }\end{array}$ & OKE 2015 & $\mathrm{~S}$ \\
\hline $\mathrm{X} 10$ & $\begin{array}{l}\text { Średni wynik egzaminu gimnazjalnego - mate- } \\
\text { matyka [w \%] }\end{array}$ & OKE 2015 & $\mathrm{~S}$ \\
\hline $\mathrm{X} 11$ & $\begin{array}{l}\text { Średni wynik egzaminu gimnazjalnego - przy- } \\
\text { roda }[\mathrm{w} \%]\end{array}$ & OKE 2015 & $\mathrm{~S}$ \\
\hline $\mathrm{X} 12$ & $\begin{array}{l}\text { Średni wynik egzaminu gimnazjalnego - język } \\
\text { obcy poziom podstawowy [w \%] }\end{array}$ & OKE 2015 & $\mathrm{~S}$ \\
\hline $\mathrm{X} 13$ & $\begin{array}{l}\text { Średni wynik egzaminu gimnazjalnego - język } \\
\text { obcy poziom rozszerzony [w \%] }\end{array}$ & OKE 2015 & $\mathrm{~S}$ \\
\hline $\mathrm{X} 14$ & $\begin{array}{l}\text { Udział dzieci w placówkach wychowania przed- } \\
\text { szkolnego na } 1 \text { tys. dzieci w wieku 3-5 lat [w \%] }\end{array}$ & $\begin{array}{c}\text { BDL } \\
2012-2014 *\end{array}$ & $\mathrm{~S}$ \\
\hline $\mathrm{X} 15$ & $\begin{array}{l}\text { Udział radnych z wyższym wykształceniem } \\
\text { w ogólnej liczbie ludności dorosłej [w \%] }\end{array}$ & $\begin{array}{l}\text { GUS BDL } \\
2014\end{array}$ & $\mathrm{~S}$ \\
\hline
\end{tabular}

* Średnia z lat 2012-2014.

Objaśnienia: OKE - Okręgowa Komisja Egzaminacyjna, NSP - Narodowy Spis Powszechny, BDL - Bank Danych Lokalnych, GUS - Główny Urząd Statystyczny.

\section{Źródło: opracowanie własne}

Oceniając związki korelacyjne pomiędzy cechami, nie stwierdzono silnych współzależności o charakterze liniowym, zatem ich rozkłady przestrzenne są odmienne. W postępowaniu przyjęto założenie o równoważności każdej z cech, rezy- 
gnując tym samym z nadawania im wag w celu uniknięcia subiektywizmu ze strony autora. Ostatecznie dobór zmiennych empirycznych podyktowany był zarówno dostępnością, jak i arbitralną decyzją autora (Kukuła, 2000: 152).

\section{Rezultaty badań}

Otrzymana konfiguracja przestrzenna obszarów wiejskich potwierdza opisywany w literaturze wysoki stopień ich zdywersyfikowania, także pod względem poziomu kapitału ludzkiego, jak i jego cech cząstkowych (por. rys. 2A-2H). Wyraźnie większy potencjał kapitału koncentruje się lokalnie w gminach rozmieszczonych wokół centralnego ośrodka rozwoju, tj. miasta stołecznego Warszawy - zwłaszcza po jego zachodniej stronie oraz wokół regionalnych ośrodków wzrostu, tj. Krakowa, Poznania, Łodzi, Bydgoszczy, Torunia, Wrocławia, Szczecina. Najbardziej deficytowe okazały się słabo zurbanizowane obszary wiejskie Pomorza Środkowego, nadmorski pas województwa pomorskiego, północna część warmińsko-mazurskiego, wschodnich Kujaw i oddalone od większych miast obszary wiejskie województwa mazowieckiego. Wyraźny deficyt występuje także na terenach wiejskich położonych w zachodniej części województwa podlaskiego i dolnośląskiego oraz wschodniej części lubelskiego (por. rys. 2A-2H).

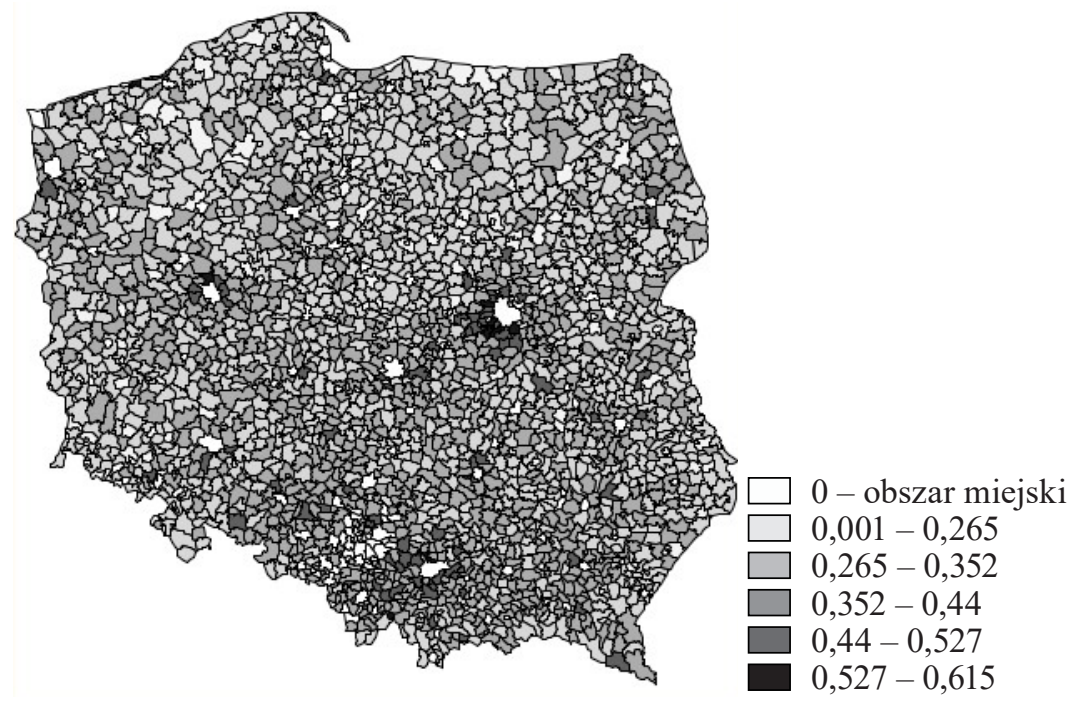

Rys. 2A. Mapa przestrzennego zróżnicowania kapitału ludzkiego na obszarach wiejskich w Polsce.

Miara syntetyczna i cechy cząstkowe. Kapitał ludzki - miara syntetyczna

Źródło: opracowanie własne na podstawie obliczeń własnych. Dane GUS, BDL, OKE 


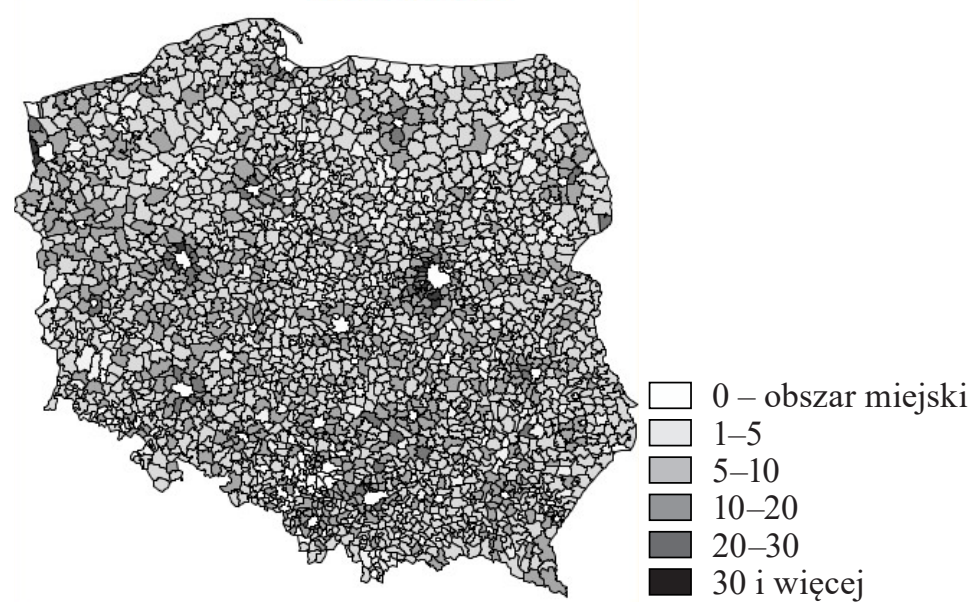

Rys. 2B. Mapa przestrzennego zróżnicowania kapitału ludzkiego na obszarach wiejskich w Polsce.

Miara syntetyczna i cechy cząstkowe. Wykształcenie ludności

Źródło: opracowanie własne na podstawie obliczeń własnych. Dane GUS, BDL, OKE

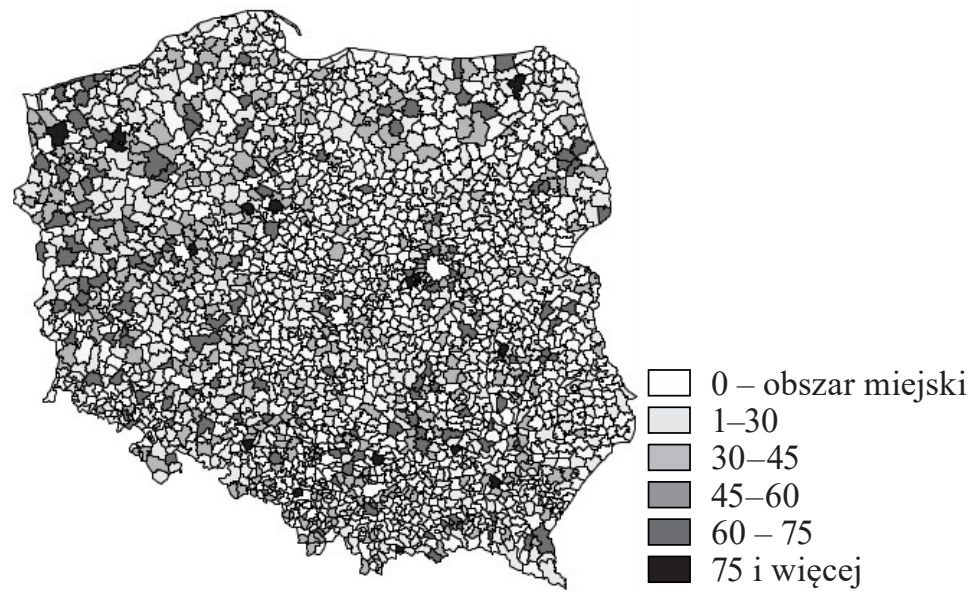

Rys. 2C. Mapa przestrzennego zróżnicowania kapitału ludzkiego na obszarach wiejskich w Polsce. Miara syntetyczna i cechy cząstkowe. Wykształcenie radnych

Źródło: opracowanie własne na podstawie obliczeń własnych. Dane GUS, BDL, OKE 


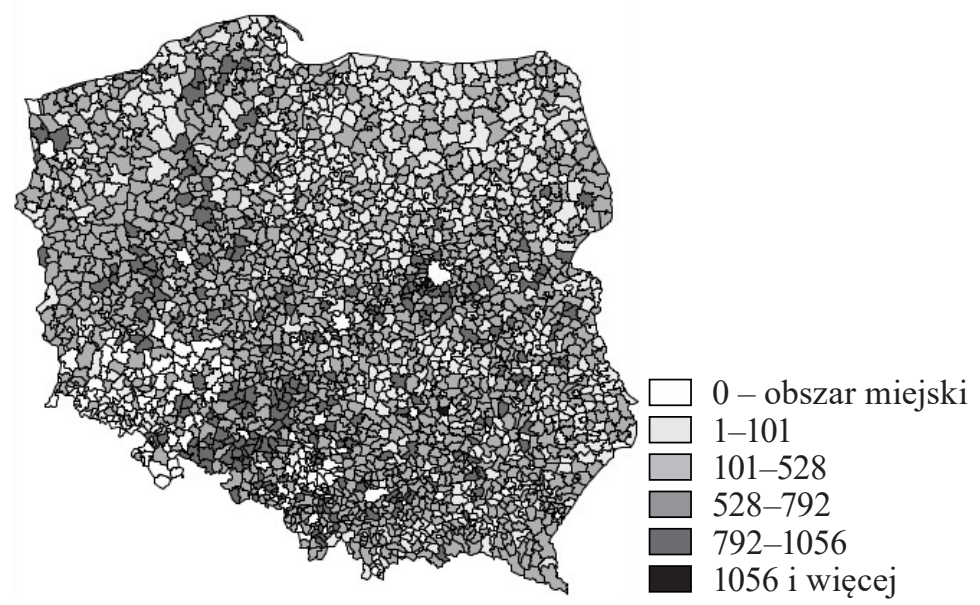

Rys. 2D. Mapa przestrzennego zróżnicowania kapitału ludzkiego na obszarach wiejskich w Polsce. Miara syntetyczna i cechy cząstkowe. Opieka przedszkolna

Źródło: opracowanie własne na podstawie obliczeń własnych. Dane GUS, BDL, OKE

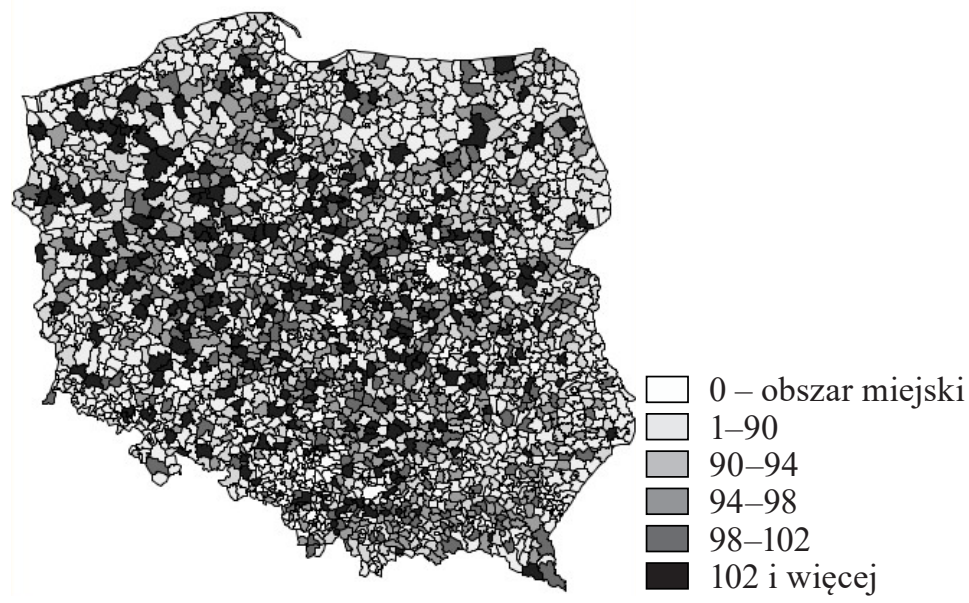

Rys. 2E. Mapa przestrzennego zróżnicowania kapitału ludzkiego na obszarach wiejskich w Polsce. Miara syntetyczna i cechy cząstkowe. Gimnazja - skolaryzacja brutto Źródło: opracowanie własne na podstawie obliczeń własnych. Dane GUS, BDL, OKE 


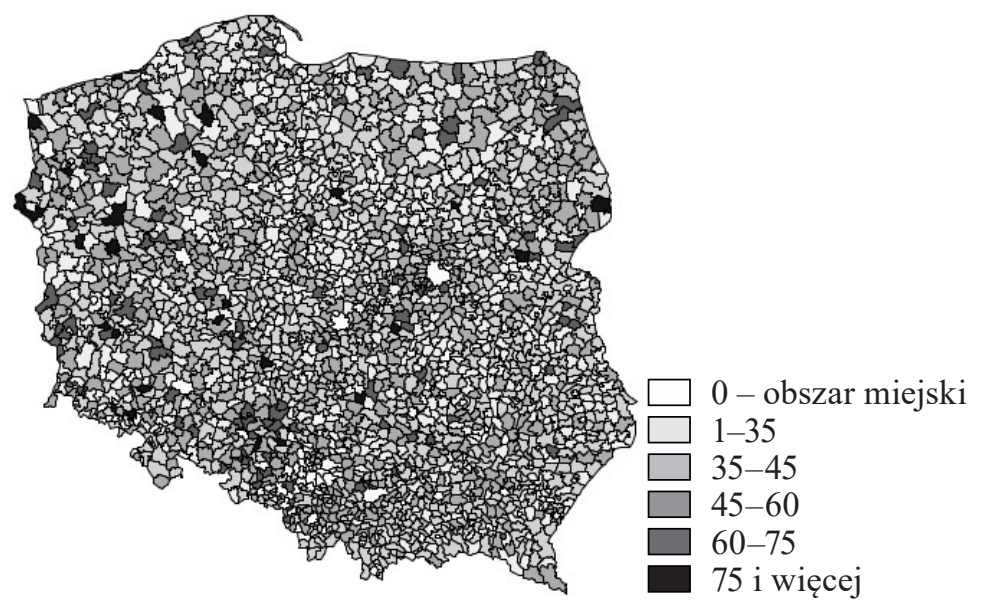

Rys. 2F. Mapa przestrzennego zróżnicowania kapitału ludzkiego na obszarach wiejskich w Polsce. Miara syntetyczna i cechy cząstkowe. Egzamin gimnazjalny - język nowożytny rozszerzony

Źródło: opracowanie własne na podstawie obliczeń własnych. Dane GUS, BDL, OKE

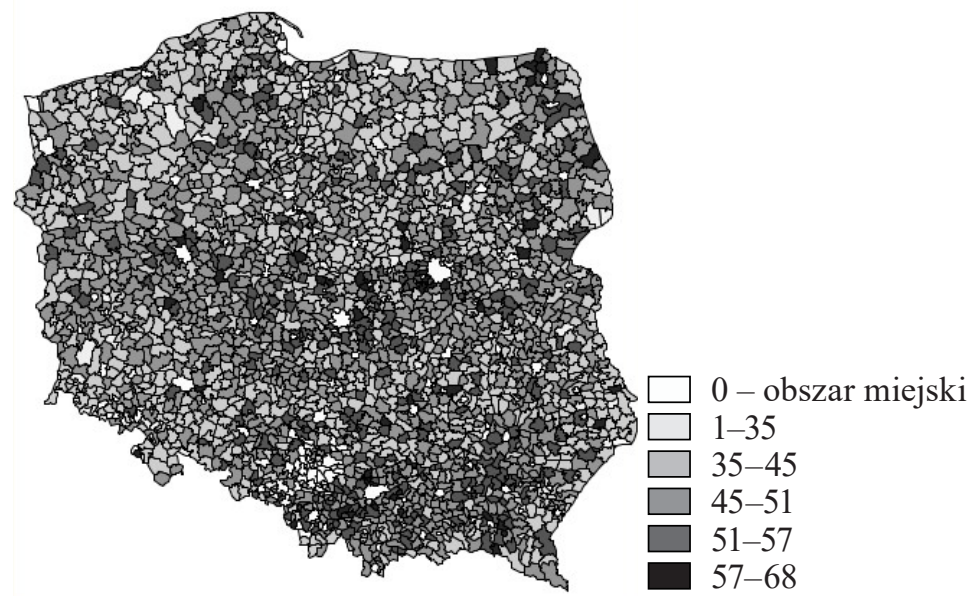

Rys. 2G. Mapa przestrzennego zróżnicowania kapitału ludzkiego na obszarach wiejskich w Polsce. Miara syntetyczna i cechy cząstkowe. Egzamin gimnazjalny - matematyka Źródło: opracowanie własne na podstawie obliczeń własnych. Dane GUS, BDL, OKE 


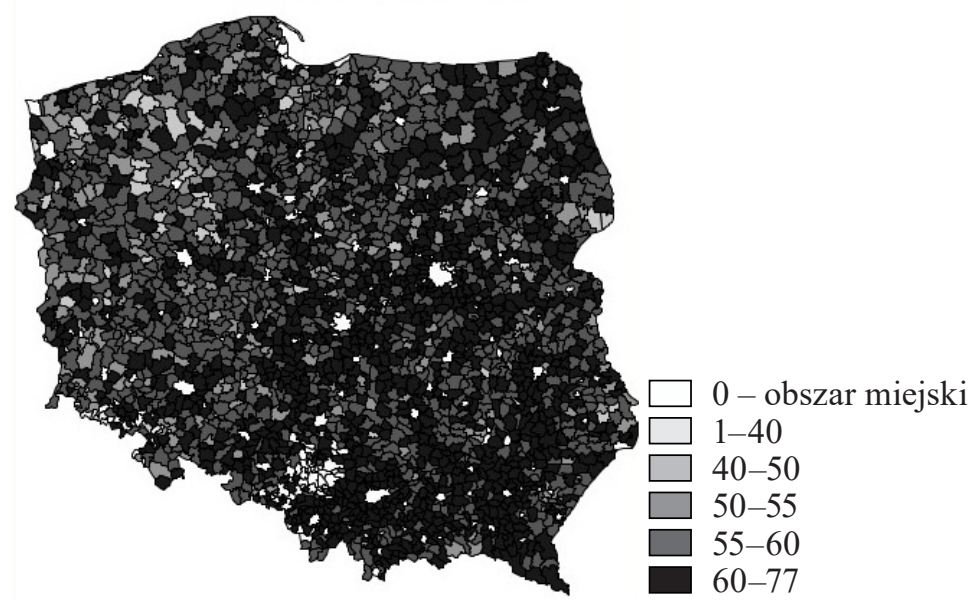

Rys. 2H. Mapa przestrzennego zróżnicowania kapitału ludzkiego na obszarach wiejskich w Polsce.

Miara syntetyczna i cechy cząstkowe. Egzamin gimnazjalny - język polski

Źródło: opracowanie własne na podstawie obliczeń własnych. Dane GUS, BDL, OKE

Syntetyczna ocena w zakresie problematyki edukacyjnej obszarów wiejskich w Polsce zobrazowana na rys. 2A wskazuje na pewne obszary o szczególnie niekorzystnej sytuacji. Klasa I to gminy o najniższym kapitale ludzkim, stanowiąca niecałe 4\% ogółu. Wymienić tu należy m.in. takie miejscowości jak: Braniewo, Lubań, Brojce, Szczecinek, Zabór, Krzęcin, Malbork, Trzeszczany. Jak wynika z przeprowadzonej analizy, klasa II okazała się najliczniejszą grupą i obejmowała $52 \%$ gmin. Podobnie jak wszystkie jednostki sklasyfikowane w grupie I, gminy te cechują się relatywnie niskim kapitałem ludzkim. Stan ten kształtowany może być przez kilka czynników.

Jak wynika z typologii strukturalnej autorstwa Rosner i Stanny z 2007 r. (Heffner, Rosner, Stanny, 2007), większość gmin z klasy I i II cechuje się niskim lub bardzo niskim poziomem rozwoju społeczno-gospodarczego. Zlokalizowane są one głównie na terenie województw: zachodniopomorskiego, warmińsko-mazurskiego, lubuskiego, wschodniej części pomorskiego. Są to obszary o słabo rozwiniętej sieci osadniczej i niskiej koncentracji ludności, gdzie aktualnie dominują gospodarstwa wielkoobszarowe. Od lat na tych terenach utrzymuje się wysokie natężenie bezrobocia (także ukrytego), co wynika z wysokiego udziału dawnego sektora państwowego w strukturze lokalnego rynku pracy i większego udziału ludności bezrolnej na wsi. Kolejną cechą wynikającą z zaszłych czynników jest niska aktywność społeczna i gospodarcza mieszkańców tych obszarów, co w konsekwencji przekłada się na duży udział ludności korzystającej z pomocy społecznej. Ten typ gmin koncentruje się także w innych nieatrakcyjnych migracyjnie regionach kraju: północnej części województwa mazowieckiego, w Kotlinie Kłodzkiej, zachodniej części województwa dolnośląskiego i lubuskiego, w rejo- 
nach skrajnie rozdrobnionego rolnictwa rodzinnego (wschodnia ściana woj. lubelskiego i woj. podkarpackie) oraz monofunkcyjnych rolniczo Kujaw. Rzadko występują natomiast pomiędzy strefą aglomeracji warszawskiej i łódzkiej, na zwartym obszarze województw: opolskiego, śląskiego i małopolskiego, a więc w takich rejonach, gdzie koncentracja ludności jest wysoka i które cechuje relatywnie ponadprzeciętny kapitał ludzki.

Kolejną względnie homogeniczną grupę stanowią gminy o średnim poziomie kapitału ludzkiego (klasa III). Są one formą przejściową i tworzą tzw. strefę buforową pomiędzy podmiejską strefą dużych miast a obszarami peryferyjnymi. Obszary te cechują się stosunkowo dużym zaludnieniem. Największą koncentrację gmin tego typu obserwuje się w promieniu dużych miast lokalnych (Wielkopolska, Mazowsze, Podlasie). Zwarty koncentrycznie obszar gmin typu III występuje na terenie województwa opolskiego, śląskiego oraz małopolskiego, a więc wszędzie tam, gdzie w sąsiedztwie występuje ośrodek miejski pełniący funkcję lokalnego ośrodka wzrostu. Najkorzystniejsza sytuacja rysuje się w gminach usytuowanych w tzw. strefie zewnętrznej największych miast w Polsce (klasa IV i V), głównie wokół regionalnych biegunów wzrostu i centralnego ośrodka - Warszawy. Gminy te pozostają w strefie bezpośredniego oddziaływania rynku pracy dużego miasta, co korzystnie kształtuje strukturę społeczno-zawodową ich mieszkańców. Wyjątek stanowią gminy nadmorskie: Ustronie Morskie i Rewal, czerpiące niekwestionowane korzyści z tzw. renty położenia. Łączny udział gmin w całej populacji jest jednak znikomy i wynosi niewiele ponad 4\% (94 gminy).

Tabela 2: Podstawowe charakterystyki wyodrębnionych klas gmin ze względu na poziom wskaźnika KL

\begin{tabular}{|c|c|c|c|c|}
\hline $\begin{array}{c}\text { Przedział wartościowy } \\
\text { wskaźnika KL* }\end{array}$ & $\begin{array}{c}\text { Klasa } \\
\text { gminy }\end{array}$ & $\begin{array}{c}\text { Udział \% } \\
\text { w danej klasie }\end{array}$ & $\begin{array}{c}\text { Liczba obiektów } \\
\text { w danej klasie }\end{array}$ & $\begin{array}{c}\text { Średnia } \\
\text { w danej klasie }\end{array}$ \\
\hline $0,177-0,265$ & I & 3,7 & 80 & 0,243 \\
\hline $0,266-0,352$ & II & 52,0 & 1130 & 0,317 \\
\hline $0,353-0,440$ & III & 40,0 & 869 & 0,386 \\
\hline $0,441-0,527$ & IV & 3,9 & 85 & 0,463 \\
\hline $0,528-0,615$ & V & 0,4 & 9 & 0,578 \\
\hline
\end{tabular}

Źródło: Opracowanie własne

Jakość edukacji to czynnik, który istotnie różnicuje przestrzeń wiejską. Rozpiętość pomiędzy gminą o najwyższym i najniższym udziale osób z wykształceniem wyższym wyniosła: w klasie V 38 p.p., a w klasie IV i III po ok. 30 p.p. W gminach o najniższym kapitale ludzkim udział osób z wyższym wykształceniem nie przekroczył 12\%. Wartość rynkowa wykształcenia i jego dostępność dla mieszkańców wsi w ostatnich latach wyraźnie się poprawiła. Mieszkańcy obszarów wiejskich są coraz lepiej wykształceni, jednak nadal młodzież wiejska pono- 
si większe koszty związane z procesem kształcenia, zwłaszcza na poziomie średnim i wyższym, niż młodzież z miast (Klonowska-Matynia, Zdrojewski, 2008: 140-142). Wyraźnie większy udział osób z wyższym wykształceniem skumulowany jest $w$ gminach wokół dużych ośrodków miejskich, dla których bariery dostępności edukacyjnej są mniejsze niż dla mieszkańców z gmin peryferyjnych (rys. 2B). Uzupełniający ładunek informacyjny, obrazujący jakość lokalnego systemu edukacji, ma wykształcenie radnych, reprezentantów lokalnej społeczności. Aż 60\% gmin klasy I deklaruje udział radnych z wyższym wykształceniem na poziomie mniejszym niż $20 \%$, podczas gdy prawie $80 \%$ gmin klasy V i $83 \%$ gmin klasy IV deklaruje, że w ich radach zasiada 40\% i więcej osób z wyższym wykształceniem (rys. 2C).

W ogromnej większości gmin wiejskich mieszkańcy mają ograniczony dostęp do wychowania przedszkolnego. Najbardziej dogodne warunki w tym zakresie występują w obszarze silnie zaludnionych aglomeracji miejskich w województwie śląskim, opolskim, wielkopolskim oraz w strefie gmin podmiejskich Warszawy (rys. 2D).

Ocenę jakości systemu edukacji najlepiej obrazują wyniki testów kompetencji gimnazjalisty. Efekty nauczania wypadały lepiej wśród uczniów z gmin typu V i IV, podczas gdy w gminach typu I i II wyniki testów z matematyki i przyrody nie przekroczyły progu odpowiednio: 50\% i 60\%, a z części humanistycznej $65 \%$. Stwierdzono silniejsze zróżnicowanie efektów w gminach typu II i III niż w pozostałych. Jako niezadowalające uznać należy efekty nauczania języków obcych na poziomie rozszerzonym. W 49\% gmin wyniki potwierdzające umiejętności z języka nowożytnego na poziomie rozszerzonym nie przekroczyły $30 \%$. Próba ustalenia cechy najsilniej determinującej poziom wskaźnika kapitału ludzkiego nie wykazała żadnej istotnie silnej determinanty. Zastosowane równanie regresji wskazuje, że największą siłę objaśniającą okazały się mieć wyniki egzaminu gimnazjalnego $\left(\mathrm{R}^{2} 0,4-0,45\right)$, najsłabszy zaś czytelnictwo, współczynnik skolaryzacji brutto na poziomie gimnazjum $\left(\mathrm{R}^{2}<0,1\right)$ oraz opieka przedszkolna $\mathrm{i}$ wykształcenie radnych $\left(\mathrm{R}^{2}<0,2\right)$.

\section{Poziom kapitału ludzkiego a poziom rozwoju społeczno-gospodarczego}

Obszary wiejskie często poddawane są różnorodnym klasyfikacjom pod względem funkcjonalnym i strukturalnym (np. Bański, 2009; Bański, Stola, 2002: 23; KSRR, 2010: 107; Heffner, Rosner, Stanny, 2007: 220). Wykorzystując jedną z najnowszych typologii obszarów wiejskich, autorzy (Rosner, Stanny, 2014) stwierdzili, że w całej zbiorowości znikomy udział (ok. 0,4\%) mają gminy silnie zurbanizowane, cechujące 
się relatywnie najwyższym poziomem kapitału ludzkiego. Są to gminy: Konstancin Jeziorna, Zielonki, Izabelin, Ustronie Morskie, Nadarzyn, Suchy Las i Michałowice oraz Koszarawa, będąca gminą typu 4. Pozostałe gminy typu 7 to gminy sklasyfikowane w klasach IV i III, cechujące się wyższym niż przeciętny poziomem kapitału ludzkiego. Udział gmin w obu klasach zaszeregowania oszacowano łącznie na ponad 80\%. Wyjątek stanowi gmina Dobra Szczecińska, umieszczona w klasie 1.

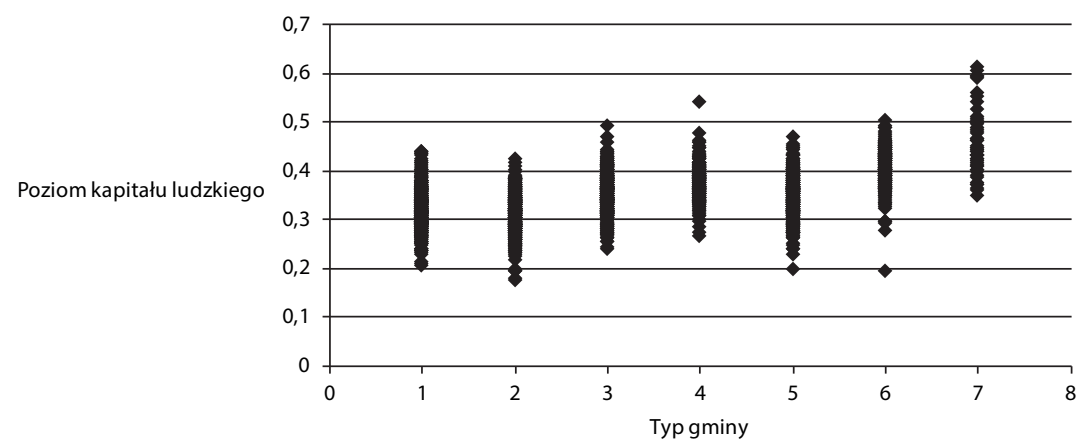

Rys. 3. Poziom rozwoju obszarów wiejskich a poziom kapitału ludzkiego

Źródło: opracowanie własne

Gminy typu 2 (z dominacją rolnictwa wielkoobszarowego) i 1 (z przewagą rolnictwa tradycyjnego) to najliczniej występujące gminy w całej zbiorowości. Generalnie gminy obu typów 1 i 2 to obszary wiejskie o najniższym poziomie kapitału ludzkiego. Gminy typu 3 (z przewagą funkcji rolniczej) i 5 (tzw. wielofunkcyjne) to obszary wiejskie charakteryzujące się niskim i średnim poziomem kapitału ludzkiego. Udział gmin obu typów w poszczególnych klasach jest podobny, $\mathrm{z}$ tą uwagą, że w obu przypadkach nie zaobserwowano obiektów w klasie V o wysokim kapitale ludzkim, a udział gmin w klasie IV jest znikomy. Gminy typu 4 opisane jako wielodochodowe z rozdrobnionym rolnictwem (dawniej tzw. chłopsko-robotnicze) w zdecydowanej większości (ponad 70\%) cechują się przeciętnym poziomem kapitału ludzkiego. Wśród gmin typu 4 nie zaobserwowano gminy w klasie I, czyli o najniższym kapitale ludzkim. W gminach typu 6, tzw. zurbanizowanych o zredukowanej funkcji rolniczej, podobnie jak w gminach typu 4, dominujący udział (ponad 70\%) mają gminy o poziomie kapitału ludzkiego klasy III. Rozkład gmin typu 6 w poszczególnych klasach zaszeregowania ze względu na poziom kapitału wskazuje na ich odwrotny układ niż miało to miejsce w przypadku gmin typu 4 . Nieco ponad 20\% gmin typu 6 to obszary o wysokim poziomie kapitału ludzkiego. Wyjątek stanowi gmina Zabór w woj. lubuskim, sklasyfikowana jako obszar o bardzo niskim kapitale. 
Tab. 3. Rozkład obiektów ze względu na typ obszaru i poziom kapitału ludzkiego

\begin{tabular}{|c|c|c|c|c|c|c|c|}
\hline \multirow[b]{3}{*}{$\begin{array}{l}\text { Klasy gmin ze względu na } \\
\text { poziom kapitału ludzkiego }\end{array}$} & \multicolumn{7}{|c|}{$\begin{array}{l}\text { Typ gminy ze względu na poziomu rozwoju } \\
\text { spoleczno-gospodarczego [udział w \%] }\end{array}$} \\
\hline & 1 & 2 & 3 & 4 & 5 & 6 & 7 \\
\hline & 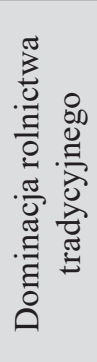 & 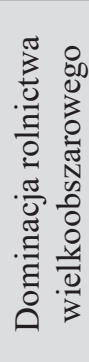 & 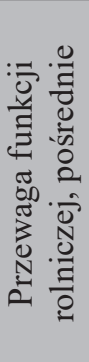 & 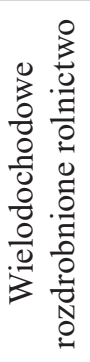 & 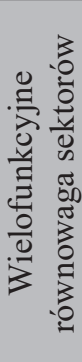 & 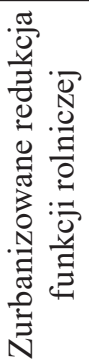 & 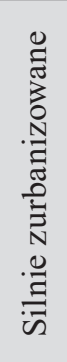 \\
\hline I & 5,5 & 9,8 & 1,1 & 0,0 & 2,1 & 0,5 & 0,0 \\
\hline II & 74,5 & 74,9 & 48,5 & 24,1 & 46,9 & 7,6 & 1,9 \\
\hline III & 19,6 & 15,3 & 49,1 & 71,1 & 49,5 & 71,1 & 40,4 \\
\hline IV & 0,4 & 0,0 & 1,3 & 4,3 & 1,6 & 20,8 & 42,3 \\
\hline $\mathrm{V}$ & 0,0 & 0,0 & 0,0 & 0,5 & 0,0 & 0,0 & 15,4 \\
\hline
\end{tabular}

Źródło: opracowanie własne

Podjęta próba ustalenia zależności istotnej statystycznie oraz siły związku wykazała, że pomiędzy badanymi cechami występuje dodatnia zależności o średniej sile².

\section{Podsumowanie}

Zebrany materiał empiryczny pozwala przyjąć tezę, że poziom kapitału ludzkiego na obszarach wiejskich w Polsce jest generalnie niski, a analizowana sfera edukacyjna jako baza do rozwoju kapitału ludzkiego wydaje się nie stwarzać wystarczająco dogodnych warunków do generowania dochodów w przyszłości przez większość badanych gmin. Z punktu widzenia możliwości rozwoju tych jednostek, fakt ten należy ocenić negatywnie. Stwierdzono również, że generalnie niższym niż przeciętnie kapitałem ludzkim cechują się obszary wiejskie oparte na rolnictwie (tradycyjnym, jak i wielkoobszarowym), znajdujące się na niższym poziomie rozwoju społeczno-gospodarczego. Bogatsze zasoby kapitału ludzkiego skoncentrowane są na obszarach wiejskich sąsiadujących z większymi ośrodkami miejskimi, zwłaszcza w regionach silnie zurbanizowanych. Wyniki analizy empirycznej zwracają również uwagę na fakt, że zarówno bogatsze, jak i biedniejsze obszary w Polsce wymagają aktywnego instrumentarium wspierającego warunki do roz-

$$
{ }^{2} \mathrm{r}=0,529 ; \mathrm{R}^{2}=0,281
$$


woju kapitału ludzkiego - instrumentarium zróżnicowanego i długookresowego, dostosowanego do ich lokalnych warunków i zasobów.

Badania dotyczące przestrzennego rozmieszczenia zasobów kapitału ludzkiego na obszarach wiejskich w Polsce potwierdzają opisywane w literaturze zdywersyfikowanie przestrzeni wiejskiej i pozwalają przyjąc jako słuszną tezę, że polaryzacja zachodząca na obszarach wiejskich ma charakter dualny. Silniejsza koncentracja kapitału ludzkiego zachodzi w stosunkowo bardzo wąskich strefach zewnętrznych największych aglomeracji miejskich, podczas gdy na przeciwległym biegunie znajdują się gminy peryferyjne o niskiej koncentracji ludności, stosunkowo niskim i bardzo niskim poziomie kapitału, czyli o relatywnie niskim potencjale rozwojowym.

Oceniając kierunek przestrzennego rozmieszczenia kapitału ludzkiego na obszarach wiejskich w Polsce należy uznać, że rysuje się on w układzie centrum - peryferia. Nie jest natomiast zauważalna, chociaż jest często opisywana w literaturze, polaryzacja przestrzenna obszarów wiejskich w układzie wschód - zachód. Otrzymany rozkład przestrzenny kapitału ludzkiego jest zgodny z oczekiwaniami autora i potwierdza tezę, że współcześnie najsilniejsze procesy rozwojowe obserwuje się w największych ośrodkach wzrostu. Są one oparte na innowacyjnych technologiach i zasobach wiedzy, związanych z jakością i dostępnością systemu edukacyjnego. Teorie rozwoju regionalnego (por. Friedman, 1972: 82-107; Hirschman, 1958) także podkreślały napędzającą rolę dużych ośrodków miejskich, tzw. motorów, biegunów wzrostu w tym procesie. W świetle teorii rozwoju uzyskane wyniki badań potwierdzają dychotomiczny podział na obszary pozostające w strefie wpływu biegunów wzrostu, korzystnie oddziałujących na kształtowanie struktury zawodowej ludności oraz na te, pozostające w sferze peryferyjnej, pozbawionej takiej możliwości. Atrakcyjna lokalizacja danej jednostki w podmiejskiej strefie pozwala jej mieszkańcom czerpać korzyści z tego tytułu. To zbyt mało, by w skali globalnej mówić o wyrównanych szansach. Dostępność rynku edukacyjnego nadal sprzyja indywidualnie awansom edukacyjnym, zawodowym i społecznym, głównie mieszkańców obszarów podmiejskich. Mieszkańcy wsi peryferyjnej ponoszą większe koszty indywidualne związane z podjęciem kształcenia na poziomie ponadgimnazjalnym, i dodatkowo obciążeni są większymi kosztami społecznymi z tytułu dowozu dzieci do szkół ${ }^{3}$. Dodatkowo z przedstawionego rozkładu wynika, że oddziaływanie ośrodków centralnych, tzw. biegunów wzrostu na oddalone obszary wiejskie jest stosunkowo słabe. Promień dyfuzji nie wykracza w zasadzie poza pierścień gmin strefy podmiejskiej, silnie zurbanizowanych, podczas gdy dostęp do ośrodków edukacyjnych na peryferyjnych obszarach wiej-

${ }^{3}$ Średnio proporcjonalne wydatki na dowóz do szkół są wyższe w samorządach wiejskich aż trzystukrotnie niż w miastach! - To determinuje szanse edukacyjne na obszarach wiejskich. 
skich często nadal ogranicza się do kontaktu ze szkołą wiejską pełniącą funkcję lokalnego środka kulturalno-oświatowego.

Analiza przestrzennego rozmieszczenia kapitału ludzkiego, daje podstawy do przyjęcia tezy, że jest ono uwarunkowane oddziaływaniem czynnika historycznego, związanego z przebiegiem dawnych granic Polski. Obszary wiejskie cechujące się wyższym kapitałem ludzkim układają się w granicach przedwojennej Polski, w przeciwieństwie do obszarów Pomorza Środkowego, Warmii i Mazur, jak i całej ściany zachodniej Polski, włączonych w struktury państwa po $1945 \mathrm{r}$. Nowa powojenna historia tych ziem wydaje się okresem zbyt krótkim na odbudowę kapitału na tych terenach. Poziom wiedzy i kultura są co prawda dziedzictwem przeszłości, a niwelacja różnic ukształtowanych historycznie jest procesem długotrwałym. Jednak należy mieć nadzieję, że długookresowe inwestycje zaplanowane optymalnie do warunków lokalnych mogą przynieść wymierne efekty.

\section{Bibliografia}

Amsden A. (1992), Asia's Next Giant: South Korea and Late Industrialization, Oxford University Press, New York.

Bański J. (2009), Typy obszarów funkcjonalnych w Polsce, Ekspertyza dla MRR, IGiPZ PAN, Warszawa.

Bański J., Stola W. (2002), Przemiany struktury przestrzennej i funkcjonalnej obszarów wiejskich w Polsce, „Studia Obszarów Wiejskich”, t. 3, IGiPZ PAN, PTG, Warszawa.

Beach M.J. (2009), A Critique of Human Capital Formation in the U.S. and the Economic Returns to Sub-Baccalaureate Credentials. Educational Studies, „A Journal of the American Educational Studies", vol. 45(1), s. 24-38.

Becker G.S. (1975), Human Capital, New York.

Becker G.S. (1993), Human capital. A theoretical and empirical analysis, with special reference to education, 3rd ed., Chicago University Press, Chicago-London.

Carnoy M., Castells M. (2001), Globalisation, the Knowledge Society and the Network State: Poulantzas at the Millennium, „Global Networks”, vol. 1(1), s. 1-18.

Cuhna F., Heckman J.J., Lochner L., Masterov D.V. (2005), Interpreting the evidence on life cycle skill formation, Discussion Paper Series IZA DP No. 1675, Forschungsinstitut zur Zukunft der Arbeit, Institute for the Study of Labor, Bonn.

Czapiewski K. (2011), Czy struktura funkcjonalna warunkuje zaistnienie sukcesu na obszarach wiejskich, [w:] W. Kamińska, K. Heffner (red.), Dychotomiczny rozwój obszarów wiejskich, Studia KPZK PAN, t. CXXXVIII, Warszawa.

Domański R. (2007), Gospodarka przestrzenna. Problemy teoretyczne, PWN, Warszawa 2007.

Fuente A. de la, Ciccone A. (2003), Human capital in the global and knowledge-based economy. Final Report, Employment and European Social Found, Luxemburg.

Friedmann J. (1972), A general theory of polarized development, [w:] N.M. Hansen (ed.), Growth Centres in Regional Economic Development, Free Press, New York.

Gaczek W.M., Komorowski J. (2005), Kapitał ludzki i społeczny regionu jako element rozwoju gospodarki opartej na wiedzy, [w:] W. M. Gaczek (red.), Innowacje w rozwoju regionu, ,Zeszyty Naukowe Akademii Ekonomicznej w Poznaniu", z. 57, Wydawnictwo AE w Poznaniu, Poznań, s. 54-55.

Green A. (1997), Education, Globalization and the Nation State, MacMillan, Basingstoke. 
Hanushek E.A., Woessmann L. (2008), The role of cognitive skills in economic development, „,Journal of Economic Literature", vol. XLVI, 46:3, s. 607-668.

Hanushek E.A., Woessmann L. (2011), The Economics of International Differences in Educational Achievement, [in:] E. Hanushek, S. Machin, L. Woessman (eds.), Handbook of the Economics of Education, vol. 3, North Holland, Amsterdam, s. 89-200.

Heffner K., Rosner A., Stanny M. (2007), Poziom rozwoju społeczno-gospodarczego obszarów wiejskich a dynamika przemian, [w:] A. Rosner (red.), IZróżnicowanie poziomu rozwoju spoteczno-gospodarczego obszarów wiejskich a zróżnicowanie dynamiki zmian, RWIR PAN, Warszawa.

Hirschman A.O. (1958). The Strategy of Economic Development, Yale University Press, New Haven. Hughes R. (1991), Examining the Roots of Educational Demand: The Case Supporting Rural Agrarian Development, ,World Development”, vol. 19(2/3), s. 213-23.

Jabłoński Ł. (2011), Kapitał ludzki w wybranych modelach wzrostu gospodarczego, „Gospodarka Narodowa" nr 1-2.

Jabłoński Ł. (2012), Kapitał ludzki a konwergencja gospodarcza, C.H. Beck, Warszawa.

Klonowska-Matynia M., Zdrojewski E.Z. (2008), Wyksztatcenie jako determinanta rozwoju kapitału ludzkiego na obszarach wiejskich, „Studia i Prace Wydziału Nauk Ekonomicznych i Zarządzania", nr 8, Wydawnictwo Naukowe Uniwersytetu Szczecińskiego, Szczecin, s. 139-144.

Koncepcja Przestrzennego Zagospodarowania Kraju 2030 (2012), Ministerstwo Rozwoju Regionalnego, Warszawa.

Kozuń-Cieślak G. (2013), Efektywność inwestycji publicznych w kapitat ludzki, „Ekonomista”, nr 3, s. 321-322.

Kukuła K. (2000), Metoda unitaryzacji zerowanej, Wydawnictwo Naukowe PWN, Warszawa.

Lucas R.E. (1988), On the mechanics of economic development, „Journal of Monetary Economic” vol. 22, Elsevier Science Publishers, North-Holland, s. 4-5.

Mazur M., Bański J., Czapiewski K., Śleszyński P. (2015), Wiejskie obszary funkcjonalne - próba metodyczna wyznaczenia ich obszarów i granic, „Studia Obszarów Wiejskich”, t. 37, IGiPZ PAN, PTG, Warszawa. s. 7-36.

Mincer J. (1962), On-the-job Training: Costs, Returns and Some Implications, „Journal of Political Economy", vol. 70, no. 5, part 2, s. 50-79.

Nelson R.R., Phelps S. (1966), Investment in humans, technological diffusion and economic growth, „American Economic Review”, t. 56/1-2, s. 69-75.

Nowak E. (1990), Metody taksonomiczne w klasyfikacji obiektów społeczno-gospodarczych, PWE, Warszawa.

Obszary wiejskie w Polsce w 2014 roku (2014), Studia i analizy statystyczne, GUS , WarszawaOlsztyn.

Oketch M.O. (2003), Affording the Unaffordable: Cost-Sharing in Higher Education in Sub-Saharan Africa, „Peabody Journal of Education”, vol. 78(3), s. 88-106.

Oketch M.O. (2004), The Emergence of Private University Education in Kenya: Trends, Prospects and Challenges, „International Journal of Educational Development”, vol. 24, s. 119-136.

Oketch M.O. (2006), Determinants of Human Capital Formation and Economic Growth of African Countries, „Economics of Education Review”, vol. 25(5), s. 554-564.

Romer P.M. (1992), Endogenous technological change, ,Journal of Political Economy”, t. 98, nr 5, vol. 2, The University of Chicago Press, Chicago.

Rosner A., Stany M. (2014), Monitoring Rozwoju Obszarów Wiejskich. Etap I, FEFRWP, IRWiR PAN, Warszawa.

Schultz T.W. (1963), The Economic Value of Education, New York.

Schultz T.W. (1980), Investment In Entrepreneurial Ability, „Scandinavian Journal of Economics”, vol. 82(4), s. 437-48. 
Stanny M. (2013), Przestrzenne zróżnicowanie rozwoju obszarów wiejskich w Polsce, IRWiR PAN, Warszawa.

Stanny M., Czarnecki A. (2011), Zrównoważony rozwój obszarów wiejskich Zielonych Płuc Polski. Próba analizy empirycznej, IRWiR PAN, Warszawa.

Stola W. (1987), Klasyfikacja funkcjonalna obszarów wiejskich Polski. Próba metodyczna, „Prace Habilitacyjne", IGiPZ PAN, Warszawa.

Tilak J. (2002), Building Human Capital in East Asia: What Others Can Learn, National Institute of Educational Planning and Administration, New Delhi.

Tilak J. (2004), Public Subsidies in Education in India, „Economic and Political Weekly of India”, vol. 39, s. 343-359.

Weisbrodt B.A. (1962), Education and investment in human capital, „Journal of Political Economy", vol. 70, no. 5, The University of Chicago Press, Chicago, s. 106-123.

\title{
Educational Factors and Spatial Distribution of Human Capital in Rural Areas in Poland
}

\begin{abstract}
The main objective of this article is to prepare a hierarchy and typology of rural areas in Poland showing the level of the human capital indicator and his spatial disparities in the context of educational factors. Selected methods of multivariable objects hierarchy and classification were used in the study. In order to measure the level of human capital in rural areas the linear Indicators ordering has been applied based on the standardized sums method. As a result a relative level indicator of Human Capital has been assigned to each area. As a part of the research analysis will be carried out in spatial dimension. Studies confirm that: generally, the level of human capital on rural areas is low; the diversification of the rural space is relatively strong, the polarization has a dual character (center - periphery), the high quality sphere of education and the availability dominate still in the growth centers, and the radius of diffusion does not go in principle outside the ring suburban zone. The subject of the spatial analysis will be rural areas in Poland, in particular their human capital indicators. GUS BDL, NSP, OKE were the main data source.
\end{abstract}

Keywords: rural areas, human capital, education, diversification

JEL: C40, C31, O15, 125

\begin{tabular}{|l|l|}
\hline \multirow{2}{*}{ OPEN ACCESS } & $\begin{array}{l}\text { C by the author, licensee Łódź University - Łódź University Press, Łódź, Poland. } \\
\text { This article is an open access article distributed under the terms and conditions } \\
\text { of the Creative Commons Attribution license CC-BY } \\
\text { (http://creativecommons.org/licenses/by/3.0/) }\end{array}$ \\
\cline { 2 - 2 } \\
Received: 2016-08-14; verified: 2016-12-20. Accepted: 2017-02-15.
\end{tabular}

